Matthias Weil*, Uwe Kolitsch and Tobias Stürzer

\title{
Dimorphism of $\mathrm{MnHAsO}_{4}\left(\mathrm{H}_{2} \mathrm{O}\right)$ : natural monoclinic krautite and its synthetic triclinic modification
}

https://doi.org/10.1515/znb-2021-0184

Received December 18, 2021; accepted January 11, 2022;

published online February 7, 2022

Abstract: The crystal structure of natural krautite, $\mathrm{MnHAsO}_{4}\left(\mathrm{H}_{2} \mathrm{O}\right)$, was re-evaluated from a cotype specimen, confirming the previously reported monoclinic symmetry for this mineral (space group $P 2_{1}, Z=8, a=8.0093$ (5), $b=15.9372(10), c=6.8065(4) \AA, \beta=96.534(2)^{\circ}$ at room temperature, 5662 structure factors, 302 parameters, $R 1=0.0295, w R 2=0.0770)$. Although hydrogen atoms could not be located from the single crystal X-ray diffraction study, the higher accuracy and precision of the results allowed to derive the hydrogen-bonding scheme $(\mathrm{O} \cdots \mathrm{O}=2.55-2.90 \AA)$ in the crystal structure of krautite. Crystals of synthetic $\mathrm{MnHAsO}_{4}\left(\mathrm{H}_{2} \mathrm{O}\right)$ were grown by mixing aqueous solutions of $\mathrm{NH}_{4} \mathrm{H}_{2} \mathrm{AsO}_{4}$ and $\mathrm{MnSO}_{4}$ and keeping the formed gel at $105{ }^{\circ} \mathrm{C}$ for several days. The obtained triclinic crystals were systematically and polysynthetically twinned by contact on (010). Separation of reflections from two individual domains made it possible to determine and refine the crystal structure (space group $P \overline{1}, Z=8, a=8.0105(16), b=15.991(4), c=6.8029(12) \AA$, $\alpha=92.635(8), \beta=96.534(2), \gamma=90.151(8)^{\circ}$ at room temperature, 7226 structure factors, 255 parameters, $R 1=0.0445, w R 2=0.1381)$. The triclinic polymorph of $\mathrm{MnHAsO}_{4}\left(\mathrm{H}_{2} \mathrm{O}\right)$ does not show a direct group-subgroup relation with monoclinic krautite. Triclinic $\mathrm{MnHAsO}_{4}\left(\mathrm{H}_{2} \mathrm{O}\right)$ is closely related with other triclinic $M^{\mathrm{II}} \mathrm{HAsO}_{4}\left(\mathrm{H}_{2} \mathrm{O}\right)$ $(M=\mathrm{Co}, \mathrm{Cu}, \mathrm{Zn}, \mathrm{Mg}$ ) mineral phases. Quantitative structural comparisons between the five $M^{\mathrm{II}} \mathrm{HAsO}_{4}\left(\mathrm{H}_{2} \mathrm{O}\right)$ compounds revealed a high similarity between the $\mathrm{Mn}$ and Co members, and between the $\mathrm{Zn}$ and $\mathrm{Mg}$ members,

*Corresponding author: Matthias Weil, Institute for Chemical Technologies and Analytics, Division of Structural Chemistry, TU Wien, Getreidemarkt 9/164-SC, 1060 Vienna, Austria,

E-mail: Matthias.Weil@tuwien.ac.at

Uwe Kolitsch, Mineralogisch-Petrographische Abteilung, Naturhistorisches Museum, Burgring 7, 1010 Vienna, Austria; and Institut für Mineralogie und Kristallographie, Universität Wien, Althanstraße 14, 1090 Vienna, Austria

Tobias Stürzer, Bruker AXS GmbH, Östliche Rheinbrückenstraße 49, 76187 Karlsruhe, Germany respectively. Subtle distinctions between the two pairs are ascribed to a different hydrogen-bonding scheme. Although the $\mathrm{Cu}$ member has a similar hydrogen-bonding scheme as the Mn and Co pair, its structural similarity with triclinic $\mathrm{MnHAsO}_{4}\left(\mathrm{H}_{2} \mathrm{O}\right)$ is low due to the strain of the crystal structure caused by the Jahn-Teller distortions of the $\left[\mathrm{CuO}_{6}\right]$ octahedra.

Keywords: arsenate; crystal structure (re)determination; manganese; mineral phases; structural relation; dimorphism.

Dedicated to Professor Christian Näther on the occasion of his 60th birthday.

\section{Introduction}

A multitude of anhydrous or hydrous phases exist in the system $\mathrm{Mn} / \mathrm{As} / \mathrm{O} / \mathrm{H})$, both in the form of minerals or as synthetic compounds. Part of these phases have extensively been used as insecticides during the first part of the 20 th century [1]. Due to the persistent toxicity of arsenic not only for beneficial insects but also for mammals, application of arsenic-containing crop-protecting agents was later banned [2]. Nevertheless, arsenic remains one of the naturally most abundant hazardous substances [3], with particular risks for poisoning drinking water sources in some areas of the world like in Bangladesh [4]. For identification of these inorganic phases in soils, detailed knowledge of their formation conditions and crystal structures is required. The great number of naturally occurring arsenic compounds can be explained by the ability of arsenic acid to form different types of anions that can be present as isolated tetrahedral species like $\mathrm{AsO}_{4}{ }^{3-}$, $\mathrm{HAsO}_{4}{ }^{2-}, \mathrm{H}_{2} \mathrm{AsO}_{4}{ }^{-}$or as condensed anions with arsenic in a tetrahedral and/or an octahedral coordination by oxygen [5]. Another reason for the diversity within the system $\mathrm{Mn} / \mathrm{As} / \mathrm{O} / \mathrm{H})$ pertains to the different stable oxidation states that both $\mathrm{Mn}$ and As can exhibit, viz. +II/+III and $+\mathrm{III} /+\mathrm{V}$, respectively. Table 1 compiles crystallographic data for all $\mathrm{Mn} / \mathrm{As} / \mathrm{O} / \mathrm{H})$ phases that have been structurally characterized and deposited in the Inorganic Crystal Structure Database (ICSD [6]) up to date. 
Table 1: Crystallographic literature data (in $\AA{ }^{\circ}{ }^{\circ}$ ) of phases in the $\mathrm{Mn} / \mathrm{As} / \mathrm{O} /(\mathrm{H})$ system. Oxidation states for manganese (+II or +III) and for arsenic (+III) are indicated; all other phases contain arsenic in oxidation state $+\mathrm{V}$.

\begin{tabular}{|c|c|c|c|c|c|c|c|c|}
\hline Phase; mineral name & Space group & $a$ & $\boldsymbol{b}$ & $c$ & $\alpha$ & $\beta$ & $\gamma$ & Ref. \\
\hline$\alpha-\mathrm{Mn}_{3}{ }_{3}\left(\mathrm{AsO}_{4}\right)_{2} ;-$ & $P 2_{1} / n$ & 5.4278 & 6.8421 & 9.1696 & 90 & 96.480 & 90 & [7] \\
\hline$\beta-\mathrm{Mn}_{3}{ }_{3}\left(\mathrm{AsO}_{4}\right)_{2} ;-$ & $P 2_{1} / c$ & 9.1129 & 11.7658 & 6.4204 & 90 & 98.727 & 90 & [7] \\
\hline $\mathrm{Mn}_{2}{ }_{2} \mathrm{As}_{2} \mathrm{O}_{7} ;-$ & $\mathrm{C} 2 / \mathrm{m}$ & 6.7454 & 8.7561 & 4.8004 & 90 & 102.723 & 90 & [8] \\
\hline $\mathrm{Mn}^{\mathrm{N}} \mathrm{As}_{2} \mathrm{O}_{6} ;-$ & $P \overline{3} 1 \mathrm{~m}$ & 4.7956 & 4.7956 & 4.6923 & 90 & 90 & 120 & [9] \\
\hline $\mathrm{Mn}^{\mathrm{III}} \mathrm{AsO}_{4} ;-$ & $P 2_{1} / n$ & 6.6833 & 8.9303 & 4.7914 & 90 & 93.813 & 90 & [10] \\
\hline $\mathrm{Mn}_{2}{ }_{2} \mathrm{As}_{2} \mathrm{O}_{5} ;-$ & $12 / a$ & 10.1815 & 13.3254 & 14.579 & 90 & 90.096 & 90 & [11] \\
\hline $\mathrm{Mn}^{\mathrm{III}} \mathrm{AsO}_{4}\left(\mathrm{H}_{2} \mathrm{O}\right)_{1.2} ;-$ & $C 2 / c$ & 7.0311 & 7.8250 & 7.4656 & 90 & 112.145 & 90 & [12] \\
\hline $\mathrm{Mn}_{2}{ }_{2} \mathrm{As}_{2} \mathrm{O}_{7}\left(\mathrm{H}_{2} \mathrm{O}\right)_{2} ;-$ & $P 2_{1} / n$ & 6.6576 & 14.5552 & 7.8147 & 90 & 94.935 & 90 & [13] \\
\hline $\mathrm{Mn}^{\mathrm{II}}\left(\mathrm{H}_{2} \mathrm{AsO}_{4}\right)_{2}\left(\mathrm{H}_{3} \mathrm{AsO}_{4}\right)_{2} ;-$ & $P \overline{1}$ & 5.5602 & 7.4100 & 8.4276 & 100.11 & 98.578 & 92.744 & [14] \\
\hline $\mathrm{Mn}^{\prime \prime}\left(\mathrm{HAsO}_{4}\right)\left(\mathrm{H}_{3} \mathrm{AsO}_{4}\right)\left(\mathrm{H}_{2} \mathrm{O}\right)_{0.5} ;-$ & $P \overline{1}$ & 4.9750 & 5.4747 & 13.603 & 98.86 & 93.63 & 99.09 & [14] \\
\hline $\mathrm{Mn}_{5}{ }_{5} \mathrm{As}^{\mathrm{III}}{ }_{3} \mathrm{O}_{9}(\mathrm{OH}, \mathrm{Cl})$; magnussonite & $l a \overline{3} d$ & 19.680 & 19.680 & 19.680 & 90 & 90 & 90 & [15] \\
\hline $\mathrm{Mn}_{3}{ }_{3}\left(\mathrm{AsO}_{4}\right)_{2}\left(\mathrm{H}_{2} \mathrm{O}\right)_{4.5} ;$ castellaroite & $P 2_{1} / n$ & 8.7565 & 13.468 & 18.652 & 90 & 94.876 & 90 & [16] \\
\hline $\mathrm{Mn}_{2}^{\prime \prime}\left(\mathrm{AsO}_{4}\right)(\mathrm{OH}) ;$ sarkinite & $P 2_{1} / c$ & 10.2188 & 13.6127 & 12.779 & 90 & 108.834 & 90 & [17] \\
\hline $\mathrm{Mn}_{2}{ }^{\prime \prime}\left(\mathrm{AsO}_{4}\right)(\mathrm{OH}) ;$ eveite & Pnnm & 8.5478 & 8.7207 & 6.2961 & 90 & 90 & 90 & [18] \\
\hline $\mathrm{Mn}_{5}{ }_{5}\left(\mathrm{AsO}_{4}\right)_{2}(\mathrm{OH})_{4} ;$ arsenoclasite & $P 2_{1} 2_{1} 2_{1}$ & 18.290 & 5.75 & 9.31 & 90 & 90 & 90 & [19] \\
\hline $\mathrm{Mn}_{5}{ }_{5}\left(\mathrm{AsO}_{4}\right)_{2}(\mathrm{OH})_{4}\left(\mathrm{H}_{2} \mathrm{O}\right)_{4}$; akrochordite & $P 2_{1} / c$ & 5.682 & 17.627 & 6.832 & 90 & 99.49 & 90 & [20] \\
\hline $\mathrm{Mn}_{7}\left(\mathrm{AsO}_{4}\right)_{2}(\mathrm{OH})_{8} ;$ allactite & $P 2_{1} / a$ & 11.03 & 12.12 & 5.51 & 90 & 114.07 & 90 & [21] \\
\hline $\mathrm{Mn}_{7}{ }_{7}\left(\mathrm{HAsO}_{4}\right)_{4}\left(\mathrm{AsO}_{4}\right)_{2} ;-$ & $P \overline{1}$ & 6.810 & 8.239 & 10.011 & 104.31 & 108.94 & 101.25 & [22] \\
\hline $\mathrm{Mn}_{2}{ }_{2} \mathrm{Mn}^{\mathrm{III}} \mathrm{AsO}_{4}(\mathrm{OH})_{4}$; flinkite & Pnma & 9.483 & 13.030 & 5.339 & 90 & 90 & 90 & [23] \\
\hline $\mathrm{Mn}_{9}{ }_{9}(\mathrm{OH})_{9}\left(\mathrm{As}^{\mathrm{III}} \mathrm{O}_{3}\right)\left(\mathrm{As}^{\mathrm{V}} \mathrm{O}_{4}\right)_{2}\left(\mathrm{H}_{2} \mathrm{O}\right)_{2}$; synadelphite & Pnma & 10.754 & 18.865 & 9.884 & 90 & 90 & 90 & [24] \\
\hline $\mathrm{Mn"HAsO}_{4}\left(\mathrm{H}_{2} \mathrm{O}\right)$; krautite & $P 2_{1}$ & 8.012 & 15.956 & 6.801 & 90 & 96.60 & 90 & [25] \\
\hline $\left.\mathrm{Mn}_{5}\left(\mathrm{HAsO}_{4}\right)_{2}\left(\mathrm{AsO}_{4}\right)_{2}\left(\mathrm{H}_{2} \mathrm{O}\right)_{4}\right)$; miguelromeroite & $C 2 / c$ & 18.030 & 9.2715 & 9.7756 & 90 & 96.266 & 90 & [26] \\
\hline $\mathrm{Mn}^{\prime \prime} \mathrm{Mn}_{2}{ }_{2}\left(\mathrm{AsO}_{4}\right)_{2}(\mathrm{OH})_{2}\left(\mathrm{H}_{2} \mathrm{O}\right)_{4} ;$; coralloite & $P 1$ & 5.5828 & 9.7660 & 5.54551 & 94.467 & 111.348 & 93.850 & [27] \\
\hline$\left(\mathrm{Mn}_{5}{ }_{5}\left(\mathrm{H}_{2} \mathrm{O}\right)_{8}\right)\left(\mathrm{HAsO}_{4}\right)_{2}\left(\mathrm{AsO}_{4}\right)_{2}\left(\mathrm{H}_{2} \mathrm{O}\right)_{2}$; geigerite & $P \overline{1}$ & 7.944 & 10.691 & 6.770 & 80.97 & 84.20 & 81.85 & [28] \\
\hline
\end{tabular}

During hydrothermal studies aimed at growing single crystals of the manganese(II) arsenite $\mathrm{Mn}_{5}^{\mathrm{II}}\left(\mathrm{As}^{\mathrm{III}} \mathrm{O}_{3}\right)_{3}(\mathrm{OH})$, i.e. Cl-free magnussonite [15], in some of the batches synthetic krautite, $\mathrm{MnHAsO}_{4}\left(\mathrm{H}_{2} \mathrm{O}\right)$, was obtained as a minor by-product in the polycrystalline bulk, apparently generated by oxidation of $\mathrm{As}^{\mathrm{III}}$ to $\mathrm{As}^{\mathrm{V}}$. A closer examination of the original crystal structure refinement of synthetic krautite, published in 1979 [25], revealed some unsatisfactory results such as high standard uncertainties for atomic coordinates, an isotropic refinement of the displacement parameters for all atoms and a high reliability factor $R=0.112$. Hence, a more accurate crystal-structure refinement of both natural and synthetic krautite from singlecrystal data deemed appropriate. The results of these studies are presented herein.

\section{Experimental}

\subsection{Synthesis}

Crystals of synthetic krautite, $\mathrm{MnHAsO}_{4}\left(\mathrm{H}_{2} \mathrm{O}\right)$, were grown under mild hydrothermal conditions, following a modified procedure described by Dei $\beta$ [29]. At room temperature, an aqueous solution of $\mathrm{NH}_{4} \mathrm{H}_{2} \mathrm{AsO}_{4}$ was added dropwise and under constant stirring to an aqueous solution of $\mathrm{MnSO}_{4}$ which resulted in the formation of a colorless gel; the arsenate solution was added until a $\mathrm{pH}$ of $\approx 5$ was reached. The precipitate then was heated in the mother liquor in a closed vessel at $105^{\circ} \mathrm{C}$ under autogenous pressure for several days, which resulted in the formation of tabular crystals with a light-pink color and up to $0.5 \mathrm{~mm}$ in size.

Light-pink tabular crystals of natural krautite were separated from a cotype specimen (inventory number J 8927; inventoried in 1930) from Nagyág, Transsylvania (today Sacarîmb, Hunedoara Co., Romania) deposited at the Natural History Museum in Vienna, Austria. In order to ascertain the chemical composition of these crystals, representative tabular, horizontally oriented crystal and cleavage fragments were carbon-coated and studied by energydispersive X-ray analyses (EDX) using a JEOL JSM-6610LV scanning electron microscope (SEM) equipped with an energy-dispersive X-ray spectrometer (Bruker e-FlashHR+) and Bruker Esprit 2.0 software. Using an acceleration voltage of $15 \mathrm{kV}$, a counting time of $60 \mathrm{~s}$ and a dead time $<5 \%$, a total of six spot analyses of four different fragments were carried out. The spot analyses produced minor beam damage (tiny cracks in each case), probably due to loss of some water from the structure. All analyses showed that the fragments are chemically pure within standard ranges of error; only in one analysis a trace amount of Si was observed. Any $M^{\mathrm{II}}$ impurities are below the estimated detection limit of $\sim 0.02 \mathrm{at} \%$ (for Mg this limit is slightly higher due to the strong overlap of the $\mathrm{Mg} K \alpha$ peak with the As $L \alpha$ peak, despite excellent peak deconvolution by the software). The observed $\mathrm{Mn}$ :As ratio is $\approx 1: 1$.

Figure 1 shows color photomicrographs of the synthetic and natural samples. 

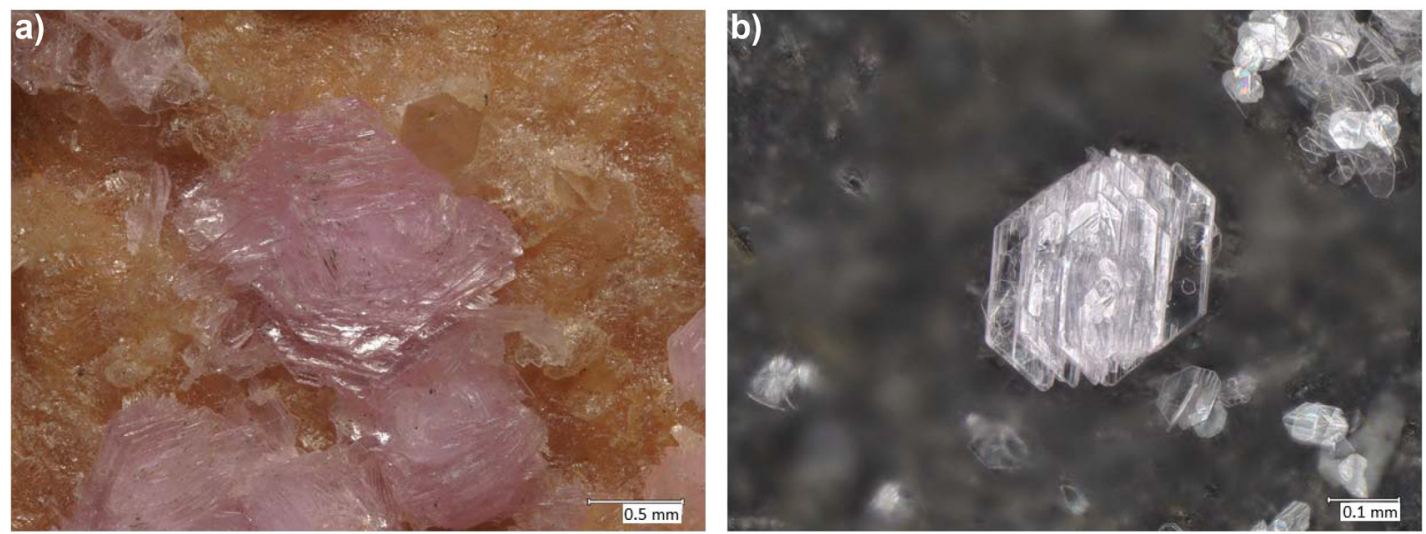

Figure 1: Color photomicrograph of (a) pale pink tabular, subparallel crystals of natural, monoclinic krautite (cotype specimen J 8927, Natural History Museum, Vienna); (b) tabular, six-sided, very pale pink crystals of synthetic triclinic $\mathrm{MnHAsO}_{4}\left(\mathrm{H}_{2} \mathrm{O}\right)$, prepared at $105^{\circ} \mathrm{C}$.

\subsection{Single crystal X-ray diffraction and structure analysis}

Inspection of the natural and synthetic krautite crystals under a polarising microscope did not indicate twinning parallel to the planes
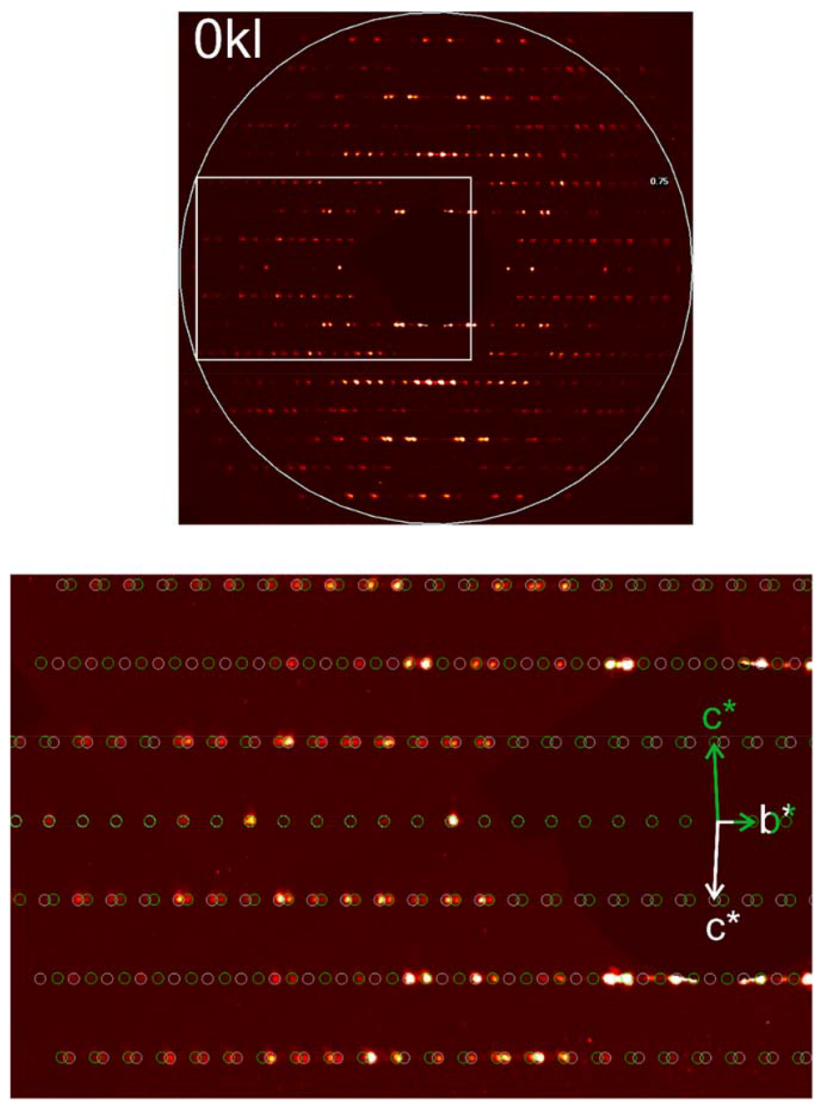

Figure 2: Reconstructed reciprocal space mapping of the $(0 \mathrm{kl})$ plane of polysynthetically twinned, synthetic triclinic $\mathrm{MnHAsO}_{4}\left(\mathrm{H}_{2} \mathrm{O}\right)$. The inset shows an enlarged area with reflections marked with green circles for one and with white circles for the second domain generated by a $180^{\circ}$ rotation about the $b^{\star}$ axis. of the plates; due to the very flat shape of the crystals, the direction perpendicular to these planes could not be examined. For crystals of the natural specimen, X-ray diffraction data were recorded on a Bruker APEX-II system (Bruker AXS, Madison, Wisconsin, USA) equipped with a microfocus X-ray tube and a graphite monochromator, applying Mo $K \alpha$ radiation $(\lambda=0.71073 \AA$ ). For the synthetic crystals, the same type of radiation was used on a Bruker D8 QUEST system (Bruker AXS $\mathrm{GmbH}$, Karlsruhe, Germany) equipped with an INCOATEC Microfocus Sealed Tube 3.0 and a multilayer mirror monochromator. Data sets for both types of crystals were measured at room temperature and at $-173^{\circ} \mathrm{C}$ to check for possible phase transitions in this temperature range, with each data collection strategy handled and optimized with APEX-3 [30]. For synthetic $\mathrm{MnHAsO}_{4}\left(\mathrm{H}_{2} \mathrm{O}\right)$ a close inspection of the diffraction data by using reconstructed reciprocal planes showed that all investigated crystals have triclinic symmetry and were in fact polysynthetically twinned. Use of CELL_Now [30] revealed a $180^{\circ}$ rotation about the $b^{\star}$ axis that transfers one domain into the other (Figure 2). For integration of reflection intensities using a narrowframe algorithm with SAINT [30], the contributions of each domain and overlapping reflections were separated and written into an HKLF-5 file that eventually was used for final refinement; absorption effects were corrected with TwIN_ABS [30]. For natural krautite crystals (three crystals were investigated), monoclinic symmetry was determined, and a similar splitting of reflections like in the case of triclinic $\mathrm{MnHAsO}_{4}\left(\mathrm{H}_{2} \mathrm{O}\right)$ was not observed; for the natural crystals, data reduction and absorption correction with $\mathrm{S}_{\mathrm{ADABS}}$ [31] followed standard procedures.

The crystal structures of both natural and synthetic $\mathrm{MnHAsO}_{4}\left(\mathrm{H}_{2} \mathrm{O}\right)$ were initially solved with SHeLXT [32] and refined with SHELXL [33]. For better comparison with the previously reported structure model of monoclinic krautite and with the other members of the triclinic $M^{\mathrm{II}} \mathrm{HAsO}_{4}\left(\mathrm{H}_{2} \mathrm{O}\right)$ series, respectively, the same non-reduced unit-cells reported for $\mathrm{MnHAsO}_{4}\left(\mathrm{H}_{2} \mathrm{O}\right)$ [25] and $\mathrm{CoHAsO}_{4}\left(\mathrm{H}_{2} \mathrm{O}\right)$ [34] were chosen ${ }^{1}$, from which also atomic coordinates and the labelling scheme were adapted. The batch scaling factor for the two-component triclinic crystal of $\mathrm{MnHAsO}_{4}\left(\mathrm{H}_{2} \mathrm{O}\right)$ refined to a value of 0.35 ; monoclinic krautite was refined as a 1:1 inversion twin (Flack parameter

1 The reduced cells can be transformed from the chosen non-reduced cells by the matrix $(010,001,100)$. 
$[35]=0.502(15))$. No significant deviation from full occupancy was observed for any of the non- $\mathrm{H}$ atoms in both structures. The positions of the $\mathrm{H}$ atoms in crystals of triclinic and monoclinic $\mathrm{MnHAsO}_{4}\left(\mathrm{H}_{2} \mathrm{O}\right)$ could not be located for the two pairs of data sets and thus were not included in the final refinements. The positions of $\mathrm{O}$ atoms bonded to $\mathrm{H}$ atoms were derived from typical As- $\mathrm{O}$ bond lengths and bondvalence sum (BVS) calculations [36] using the values provided by Brese \& O'Keeffe [37]. $\mathrm{O}$ atoms that are part of an OH group are designated as $\mathrm{OH}$ with the consecutive atom number and $\mathrm{O}$ atoms of water molecules as $\mathrm{OW}$ in the same way.

Numerical details of the data collections and structure refinements are compiled in Table 2. Further details of the crystal structure investigations may be obtained from The Cambridge Crystallographic Data Centre (CCDC) on quoting the depository numbers listed at the end of Table 2. The data can be obtained free of charge via www.ccdc.cam.ac.uk/structures. Selected bond lengths and bondvalence sums (BVS) for monoclinic and triclinic $\mathrm{MnHAsO}_{4}\left(\mathrm{H}_{2} \mathrm{O}\right)$ are gathered in Table 3.

\section{Results and discussion}

Chemical analysis and crystallographic data of $\mathrm{MnHAsO}_{4}$ - $^{-}$ $\left(\mathrm{H}_{2} \mathrm{O}\right)$ were first reported on a natural sample during the first description of the mineral krautite and confirmed by the synthesis of this phase. Indexation of the diffraction pattern led to a primitive monoclinic unit cell with $a=8.00(2), b=15.93(5), c=6.79(2) \AA, \beta=96.3(5)^{\circ}$ for the natural sample. However, the crystal structure of krautite remained undetermined at this stage [38]. Due to the lack of suitable natural material at that time, the crystal structure of $\mathrm{MnHAsO}_{4}\left(\mathrm{H}_{2} \mathrm{O}\right)$ was subsequently solved from singlecrystal X-ray data of a synthetic sample in space group $P 2_{1}$ [25], thus confirming the monoclinic symmetry reported in the original description [38]. The authors noted a strong $P 2_{1} / n$ pseudo-symmetry for the final $\mathrm{MnHAsO}_{4}\left(\mathrm{H}_{2} \mathrm{O}\right)$ crystal structure model [25]. Shortly afterwards, the crystal structure determinations of analogous $\mathrm{CoHAsO}_{4}\left(\mathrm{H}_{2} \mathrm{O}\right)$ [34] (mineral name cobaltkoritnigite [39]) and $\mathrm{ZnHAsO}_{4}\left(\mathrm{H}_{2} \mathrm{O}\right)$ (koritnigite) [40] were reported, both with similar unit-cell parameters as $\mathrm{MnHAsO}_{4}\left(\mathrm{H}_{2} \mathrm{O}\right)$ but with triclinic symmetry. The same is valid for the other known members of the $M^{\mathrm{II}} \mathrm{HAsO}_{4}\left(\mathrm{H}_{2} \mathrm{O}\right)$ series, viz. $\mathrm{CuHAsO}_{4}\left(\mathrm{H}_{2} \mathrm{O}\right)$ (geminite) [41, 42] and $\mathrm{MgHAsO}_{4}\left(\mathrm{H}_{2} \mathrm{O}\right)$ (magnesiokoritnigite) [43]. Apparently, the corresponding $\mathrm{Ni}$ member " $\mathrm{NiHAsO}_{4}\left(\mathrm{H}_{2} \mathrm{O}\right)$ " has not been obtained in crystalline form [44].

The assumption that $\mathrm{MnHAsO}_{4}\left(\mathrm{H}_{2} \mathrm{O}\right)$ in fact does not belong to the monoclinic, but to the triclinic crystal system has previously been made [40] but was not confirmed afterwards. The results of the current redeterminations clearly revealed monoclinic symmetry for the natural material, and triclinic symmetry for the crystals grown under hydrothermal conditions at a temperature of $105^{\circ} \mathrm{C}$. It should be noted that crystals prepared in the same way at $90{ }^{\circ} \mathrm{C}$ in fact have monoclinic symmetry, just like single crystals grown from a gel at room temperature [25, 45] or polycrystalline material obtained by evaporation of the solvent at $60^{\circ} \mathrm{C}$ [46]. The following discussion is based on the data that resulted in the better reliability factor for each studied crystal, i.e. the $23{ }^{\circ} \mathrm{C}$ data for krautite and the $-173^{\circ} \mathrm{C}$ data for triclinic $\mathrm{MnHAsO}_{4}\left(\mathrm{H}_{2} \mathrm{O}\right)$.

\subsection{Crystal structure of krautite}

The current redetermination of natural krautite confirms the previous model [25] with higher precision and accuracy, with satisfactory reliability factors and with all atoms refined with anisotropic displacement parameters. The crystal structure of krautite is layered and comprised of (010) sheets. Within a sheet, $\left[\mathrm{MnO}_{5}\left(\mathrm{H}_{2} \mathrm{O}\right)\right](\mathrm{Mn} 1, \mathrm{Mn} 2)$ and cis-[ $\left.\mathrm{MnO}_{4}\left(\mathrm{H}_{2} \mathrm{O}\right)(\mathrm{OH})\right](\mathrm{Mn} 3, \mathrm{Mn} 4)$ octahedra are linked by edge-sharing into chains extending parallel to [101]. Adjacent chains are connected through $\mathrm{AsO}_{3}(\mathrm{OH})$ tetrahedra by sharing two corners with each of the four hydrogen arsenate anions. The average $\mathrm{Mn}-\mathrm{O}$ bond lengths of the $\left[\mathrm{MnO}_{6}\right]$ octahedra (Table 3) are in good agreement with the grand mean value of 2.199(85) $\AA$ calculated on basis of 1908 bonds and 318 polyhedra [48]. Likewise, the individual As- $\mathrm{OH}$ and $\mathrm{As}-\mathrm{O}$ distances of the $\mathrm{AsO}_{3}(\mathrm{OH})$ tetrahedra match with literature values of 1.728(19) $\mathrm{A}$ for As- $\mathrm{OH}$ bonds in $\mathrm{HAsO}_{4}{ }^{2-}$ groups and a grand mean value of $1.667(18) \AA$ for $A s-O$ bonds to nonprotonated $\mathrm{O}$ atoms [48].

The cohesion between the (010) sheets is accomplished by hydrogen-bonding interactions only, which explains the perfect cleavage parallel to $\{010\}$ described for the mineral $[25,38]$. Numerical details of the hydrogenbonding scheme are compiled in Table 4, and a view of the crystal structure including the hydrogen bonds is given in Figure 3. All $\mathrm{OH}$ groups are involved in strong hydrogen bonds to $\mathrm{O}$ atoms of $\left[\mathrm{MnO}_{5}\left(\mathrm{H}_{2} \mathrm{O}\right)\right]$ octahedra and $\mathrm{AsO}_{3}(\mathrm{OH})$ groups with $\mathrm{O} \cdots \mathrm{O}$ distances between 2.55 and $2.60 \AA$. Two of these strong interactions are intralayer hydrogen bonds to $\mathrm{O}$ atoms that are shared between $\left[\mathrm{MnO}_{5}\left(\mathrm{H}_{2} \mathrm{O}\right)\right]$ octahedra and $\mathrm{AsO}_{3}(\mathrm{OH})$ groups $(\mathrm{O} 7 \mathrm{H} \cdots 09$; $08 \mathrm{H} \cdots \mathrm{O} 10)$, and the other two strong hydrogen bonds are established between adjacent layers to $\mathrm{AsO}_{3}(\mathrm{OH})$ groups $(\mathrm{O} 15 \mathrm{H} \cdots \mathrm{O} 2$; $\mathrm{O} 16 \mathrm{H} \cdots \mathrm{01})$. The four water molecules are involved in intra- and interlayer hydrogen-bonding interactions of medium strengths with $0 \cdots 0$ distances between 2.68 and $2.90 \AA$. 


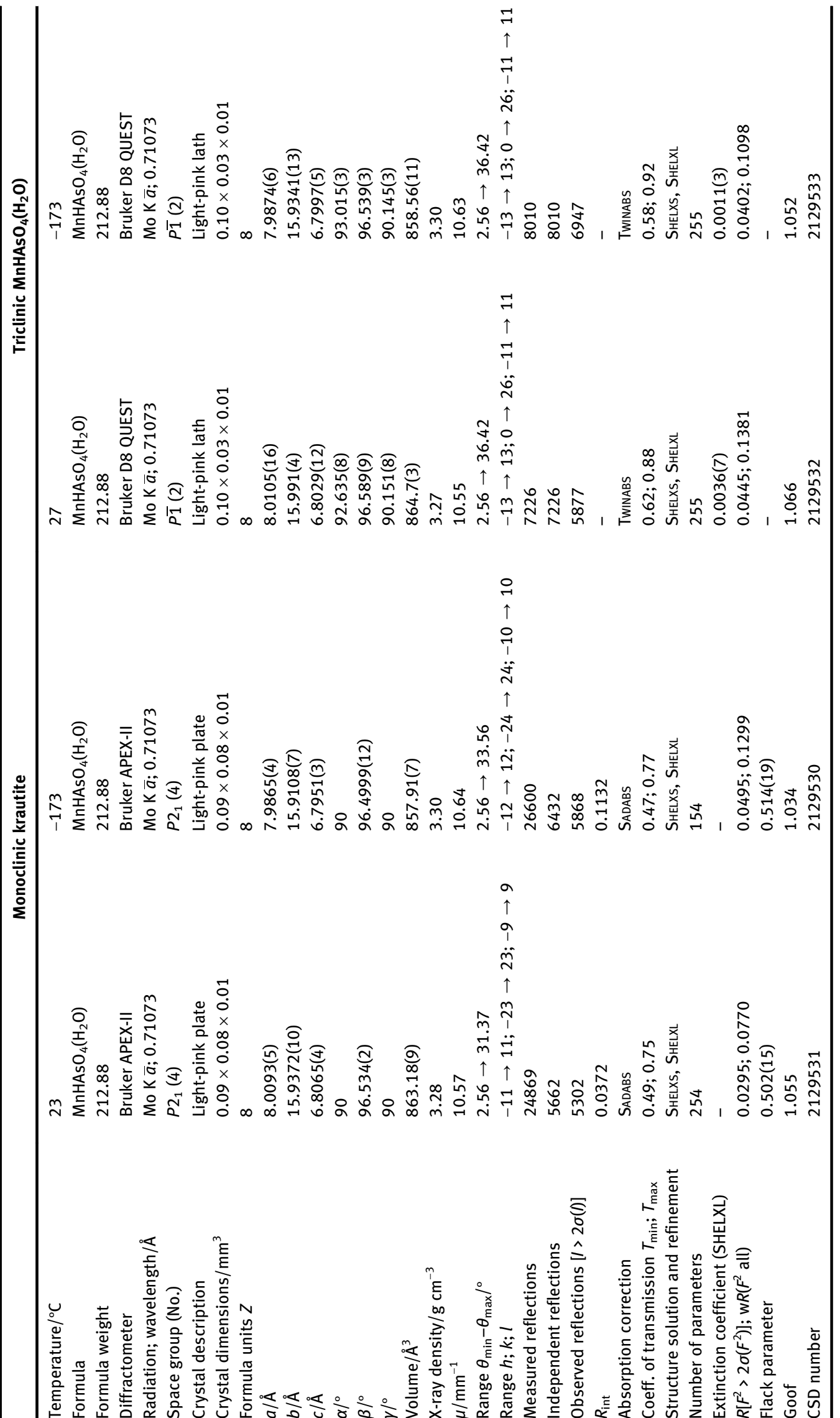


Table 3: Selected bond lengths (in $\AA$ ), their averaged values (av.) and bond-valence sums (BVS; in valence units) of the monoclinic and triclinic polymorphs of $\mathrm{MnHAsO}_{4}\left(\mathrm{H}_{2} \mathrm{O}\right)$.

\begin{tabular}{|c|c|c|c|c|c|}
\hline \multicolumn{3}{|c|}{ Monoclinic krautite at $23^{\circ} \mathrm{C}^{\mathrm{a}}$} & \multicolumn{3}{|c|}{$\begin{array}{c}\text { Triclinic } \mathrm{MnHAsO}_{4}\left(\mathrm{H}_{2} \mathrm{O}\right) \\
\text { at }-173^{\circ} \mathrm{C}^{\mathrm{a}}\end{array}$} \\
\hline Mn1 & $03^{\mathrm{i}}$ & $2.156(4)$ & Mn1 & 01 & $2.102(3)$ \\
\hline Mn1 & 012 & $2.176(4)$ & Mn1 & 03W & $2.127(4)$ \\
\hline Mn1 & 05 & $2.181(4)$ & Mn1 & 02 & $2.156(3)$ \\
\hline Mn1 & 04 & $2.193(4)$ & Mn1 & $010^{v}$ & $2.185(3)$ \\
\hline Mn1 & 017W & $2.196(5)$ & Mn1 & $01^{\mathrm{vi}}$ & $2.219(3)$ \\
\hline Mn1 & 09 & $2.252(4)$ & Mn1 & $018 \mathrm{H}^{\mathrm{vii}}$ & $2.273(3)$ \\
\hline Av.; BVS & & $2.192 ; 2.03$ & Av.; BVS & & $2.177 ; 2.13$ \\
\hline Mn2 & 04 & $2.158(4)$ & Mn2 & 05 & 2.155(3) \\
\hline Mn2 & $011^{\mathrm{ii}}$ & $2.169(4)$ & $\mathrm{Mn} 2$ & 04 & $2.172(4)$ \\
\hline Mn2 & $03^{\mathrm{i}}$ & $2.182(5)$ & $\mathrm{Mn} 2$ & $05^{\mathrm{vii}}$ & $2.186(3)$ \\
\hline Mn2 & $06^{i}$ & $2.194(4)$ & $\mathrm{Mn} 2$ & 08 & 2.193(3) \\
\hline Mn2 & $010^{\mathrm{ii}}$ & $2.222(4)$ & $\mathrm{Mn} 2$ & 06 & $2.210(3)$ \\
\hline Mn2 & 018W & $2.228(5)$ & Mn2 & 07W & $2.232(4)$ \\
\hline Av.; BVS & & $2.192 ; 2.03$ & Av.; BVS & & $2.191 ; 2.03$ \\
\hline Mn3 & 013 & $2.116(4)$ & $\mathrm{Mn} 3$ & 09W & $2.098(4)$ \\
\hline Mn3 & 019W & $2.120(6)$ & Mn3 & $016^{\mathrm{iii}}$ & $2.116(3)$ \\
\hline Mn3 & $011^{\mathrm{iii}}$ & $2.163(4)$ & Mn3 & 04 & $2.168(4)$ \\
\hline Mn3 & $06^{\mathrm{iv}}$ & $2.181(4)$ & Mn3 & 08 & $2.178(3)$ \\
\hline Mn3 & 014 & $2.233(4)$ & Mn3 & $016^{\mathrm{viii}}$ & $2.218(3)$ \\
\hline Mn3 & O7H & $2.281(4)$ & Mn3 & $015 \mathrm{H}^{\text {viii }}$ & 2.271(3) \\
\hline Av.; BVS & & $2.182 ; 2.10$ & Av.; BVS & & $2.175 ; 2.15$ \\
\hline Mn4 & 020W & $2.106(5)$ & Mn4 & $019^{\mathrm{iii}}$ & $2.148(4)$ \\
\hline Mn4 & 014 & $2.108(4)$ & Mn4 & $02^{\mathrm{ix}}$ & $2.161(3)$ \\
\hline Mn4 & 012 & $2.167(4)$ & Mn4 & 010 & $2.184(3)$ \\
\hline Mn4 & 05 & $2.181(4)$ & Mn4 & $019^{x}$ & $2.185(3)$ \\
\hline Mn4 & 013 & $2.225(4)$ & Mn4 & $011 \mathrm{~W}$ & $2.186(4)$ \\
\hline Mn4 & $08 \mathrm{H}^{\mathrm{iv}}$ & $2.279(4)$ & Mn4 & 012 & $2.244(3)$ \\
\hline Av.; BVS & & $2.178 ; 2.13$ & Av.; BVS & & $2.185 ; 2.07$ \\
\hline As1 & 01 & $1.673(4)$ & As1 & 01 & $1.678(3)$ \\
\hline As1 & 03 & $1.676(4)$ & As1 & $02^{i}$ & $1.682(3)$ \\
\hline As1 & 05 & $1.682(4)$ & As1 & $012^{\mathrm{vii}}$ & $1.684(3)$ \\
\hline As1 & $07 \mathrm{H}$ & $1.750(4)$ & As1 & $\mathrm{O} 13 \mathrm{H}$ & $1.714(3)$ \\
\hline Av.; BVS & & $1.695 ; 4.88$ & Av.; BVS & & $1.690 ; 4.93$ \\
\hline As2 & 02 & $1.664(5)$ & As2 & 014 & $1.668(3)$ \\
\hline As2 & 04 & $1.668(4)$ & As2 & 05 & $1.671(3)$ \\
\hline As2 & 06 & $1.671(4)$ & As2 & $08^{i}$ & $1.671(3)$ \\
\hline As2 & $\mathrm{O} 8 \mathrm{H}$ & $1.749(4)$ & As2 & $\mathrm{O} 15 \mathrm{H}$ & $1.751(3)$ \\
\hline Av.; BVS & & $1.688 ; 4.98$ & Av.; BVS & & $1.690 ; 4.93$ \\
\hline As3 & 013 & $1.667(4)$ & As3 & 016 & $1.670(3)$ \\
\hline As3 & 011 & $1.679(4)$ & As3 & 04 & $1.674(3)$ \\
\hline As3 & 09 & $1.681(4)$ & As3 & 06 & $1.678(3)$ \\
\hline As3 & $\mathrm{O} 15 \mathrm{H}$ & $1.716(5)$ & As3 & 017H & $1.720(3)$ \\
\hline Av.; BVS & & $1.686 ; 4.99$ & Av.; BVS & & $1.686 ; 4.99$ \\
\hline As4 & $014^{i}$ & $1.670(4)$ & As4 & 020 & $1.672(3)$ \\
\hline As4 & 012 & $1.677(4)$ & As 4 & 010 & $1.677(3)$ \\
\hline As4 & 010 & $1.683(4)$ & As 4 & 019 & $1.681(3)$ \\
\hline As4 & $\mathrm{O} 16 \mathrm{H}$ & $1.713(5)$ & As4 & $\mathrm{O} 18 \mathrm{H}$ & $1.749(3)$ \\
\hline Av.; BVS & & $1.686 ; 4.99$ & Av.; BVS & & $1.695 ; 4.88$ \\
\hline
\end{tabular}

Symmetry codes: (i) $x, y, z+1$; (ii) $x-1, y, z$; (iii) $x, y, z-1$; (iv) $x+1, y, z$; (v) $x, y-1, z$; (vi) $-x,-y,-z+1$; (vii) $-x,-y+1,-z+1$;

(viii) $-x+1,-y+1,-z+1$; (ix) $x, y+1, z$; (x) $-x+1,-y+2,-z+1$
Table 3: (continued)

\begin{tabular}{cc}
\hline Monoclinic krautite at $23^{\circ} \mathrm{C}^{\mathrm{a}}$ & Triclinic $\mathrm{MnHAsO}_{4}\left(\mathrm{H}_{2} \mathrm{O}\right)$ \\
at $-173^{\circ} \mathrm{C}^{\mathrm{a}}$
\end{tabular}

BVS of oxygen atoms and their coordination numbers (in parentheses).

Monoclinic krautite. 01 (1) 1.30; 02 (1) 1.32; 03 (3) 1.99; 04 (3) 2.01; 05 (3) 1.95; 06 (3) 1.98; 07H (2) 1.32; 08H (2) 1.32; 09 (2) 1.55; 010 (2) $1.57 ; 011$ (3) $2.00 ; 012$ (3) $1.99 ; 013$ (3) $2.03 ; 014$ (3) $2.03 ; 015 \mathrm{H}$ (1) 1.15 ; $016 \mathrm{H}$ (1) 1.16 ; $017 \mathrm{~W}$ (1) 0.33 ; $018 \mathrm{~W}$ (1) 0.31 ; $019 \mathrm{~W}$ (1) 0.41 ; O2OW (1) 0.43

Triclinic $\mathrm{MnHAsO}_{4}\left(\mathrm{H}_{2} \mathrm{O}\right) .01$ (3) 2.00; 02 (3) 1.99; $03 \mathrm{~W} 10.40 ; 04$ (3) 2.01; 05 (3) 2.02; 06 (2) 1.61; $07 \mathrm{~W}$ (1) 0.30; 08 (3) 1.94; 09W (1)

0.42 ; 010 (3) 1.95 ; $011 \mathrm{~W}$ (1) 0.34 ; 012 (2) 1.54 ; $013 \mathrm{H}$ (1) 1.14 ; 014 (1) $1.30 ; 015 \mathrm{H} \mathrm{(2)} 1.31 ; 016$ (3) 2.06 ; $017 \mathrm{H}$ (1) 1.15 ; $018 \mathrm{H}$ (2) 1.31 ; 019 (3) 1.99; 020 (1) 1.32

${ }^{\mathrm{a}}$ Bond lengths at the different temperatures $\left(-173^{\circ} \mathrm{C}\right.$ for monoclinic krautite and $27^{\circ} \mathrm{C}$ for triclinic $\mathrm{MnHAsO}_{4}\left(\mathrm{H}_{2} \mathrm{O}\right)$ ) differ by less than $0.015 \AA$ from the given values.

Table 4: Donor $\cdots$ acceptor $(D \cdots A)$ distances (in $\AA$ ) within the hydrogen-bonding networks in the $\mathrm{MnHAsO}_{4}\left(\mathrm{H}_{2} \mathrm{O}\right)$ crystal structures.

\begin{tabular}{|c|c|c|c|c|c|}
\hline \multicolumn{3}{|c|}{ Monoclinic krautite at $23^{\circ} \mathrm{C}^{\mathrm{a}}$} & \multicolumn{3}{|c|}{$\begin{array}{c}\text { Triclinic } \mathrm{MnHAsO}_{4}\left(\mathrm{H}_{2} \mathrm{O}\right) \\
\text { at }-173^{\circ} \mathrm{C}^{\mathrm{a}}\end{array}$} \\
\hline D & $\boldsymbol{A}$ & $0 \cdots 0$ distances & $\boldsymbol{D}$ & $\boldsymbol{A}$ & $0 \cdots 0$ distances \\
\hline $\mathrm{O} \mathrm{H}$ & $09^{\mathrm{iii}}$ & $2.596(7)$ & O3W & $020^{\mathrm{vii}}$ & $2.713(5)$ \\
\hline $\mathrm{O} 8 \mathrm{H}$ & $010^{\mathrm{iv}}$ & $2.589(6)$ & 03W & 07 & $2.869(5)$ \\
\hline $\mathrm{O} 15 \mathrm{H}$ & $02^{\mathrm{ii}}$ & $2.545(6)$ & 07W & $017 \mathrm{H}^{\mathrm{viii}}$ & $2.780(5)$ \\
\hline $\mathrm{O} 16 \mathrm{H}$ & $01^{i}$ & $2.588(7)$ & 07W & $014^{\mathrm{iii}}$ & $2.668(5)$ \\
\hline 017W & $015 \mathrm{H}^{\mathrm{iv}}$ & $2.736(6)$ & 09W & $014^{\text {viii }}$ & $2.680(5)$ \\
\hline 017W & 01 & $2.675(7)$ & 09W & $011 \mathrm{~W}$ & $2.795(5)$ \\
\hline 018W & $\mathrm{O} 16 \mathrm{H}$ & $2.788(7)$ & $011 \mathrm{~W}$ & 020 & $2.659(5)$ \\
\hline 018W & $02^{v}$ & $2.680(7)$ & $011 W$ & $013 \mathrm{H}^{\mathrm{vii}}$ & $2.715(5)$ \\
\hline 019W & $01^{\mathrm{vi}}$ & $2.716(8)$ & $013 \mathrm{H}$ & 014 & $2.556(5)$ \\
\hline 019W & $018 W^{i i}$ & $2.896(9)$ & $\mathrm{O} 15 \mathrm{H}$ & 06 & $2.581(5)$ \\
\hline O20W & 02 & $2.680(7)$ & 017H & 020 & $2.585(5)$ \\
\hline O20W & $017 W^{i}$ & $2.832(8)$ & $\mathrm{O} 18 \mathrm{H}$ & $012^{v}$ & $2.583(5)$ \\
\hline
\end{tabular}

Symmetry codes: (i) $-x+1, y-1 / 2,-z+1$; (ii) $-x+1, y+1 / 2,-z+1$; (iii) $x, y, z-1$; (iv) $x-1, y, z$; (v) $x, y, z+1$; (vi) $x+1, y, z$; (vii) $-x+1,-y+1,-z+1$; (viii) $-x,-y+1,-z+1$

${ }^{\mathrm{a}} \mathrm{O} \ldots \mathrm{O}$ distances at the different temperatures $\left(-173^{\circ} \mathrm{C}\right.$ for monoclinic krautite and $27^{\circ} \mathrm{C}$ for triclinic $\mathrm{MnHAsO}_{4}\left(\mathrm{H}_{2} \mathrm{O}\right)$ ) differ by less than $0.02 \AA$ from the given values.

\subsection{Crystal structure of triclinic $\mathrm{MnHAsO}_{4}\left(\mathrm{H}_{2} \mathrm{O}\right)$}

The crystal structure of triclinic $\mathrm{MnHAsO}_{4}\left(\mathrm{H}_{2} \mathrm{O}\right)$ has an apparent resemblance with that of monoclinic krautite, as recognized by the very similar unit-cell parameters 


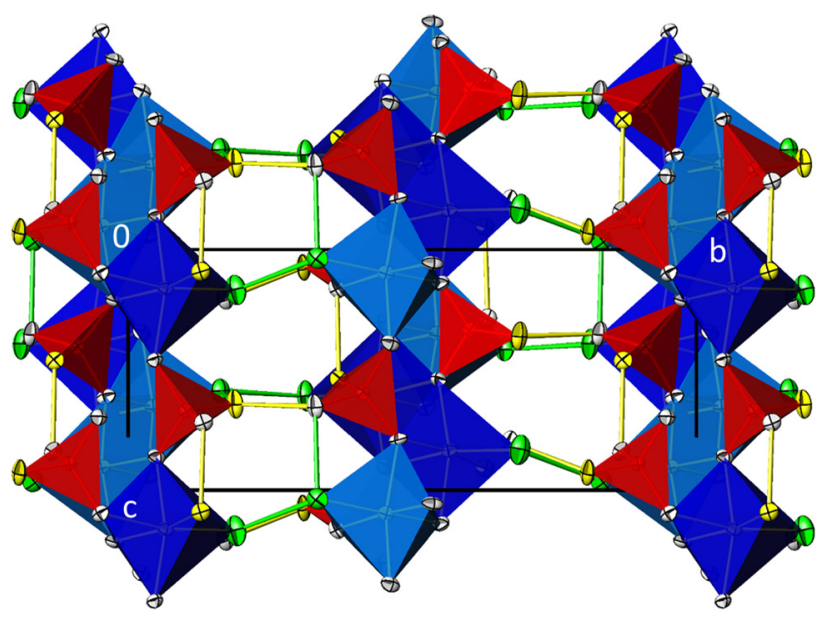

Figure 3: Crystal structure of krautite $\left(23^{\circ} \mathrm{C}\right.$ data) in polyhedral representation viewed along [100], with displacement ellipsoids drawn at the $75 \%$ probability level. $\left[\mathrm{MnO}_{5}\left(\mathrm{H}_{2} \mathrm{O}\right)\right]$ octahedra are lightblue, $\left[\mathrm{MnO}_{4}\left(\mathrm{H}_{2} \mathrm{O}\right)(\mathrm{OH})\right]$ octahedra are dark-blue and $\mathrm{AsO}_{3}(\mathrm{OH})$ tetrahedra are red. $\mathrm{O}$ atoms belonging to an $\mathrm{OH}$ group are yellow, $\mathrm{O}$ atoms of water molecules are green. Hydrogen bonds with the corresponding donor atoms are shown as lines with the same color.

(Table 2) and the same principal structure units, i.e. $\left[\mathrm{MnO}_{5}\left(\mathrm{H}_{2} \mathrm{O}\right)\right]$ and $\left[\mathrm{MnO}_{4}\left(\mathrm{H}_{2} \mathrm{O}\right)(\mathrm{OH})\right]$ octahedra, $\mathrm{AsO}_{3}(\mathrm{OH})$ tetrahedra with the corresponding bond lengths and general set-up of the crystal structure. Nevertheless, there is no direct group-subgroup relation [49] between the two crystal structures. However, a close relationship of triclinic $\mathrm{MnHAsO}_{4}\left(\mathrm{H}_{2} \mathrm{O}\right)$ exists with the other representatives of the triclinic $M^{\mathrm{II}} \mathrm{HAsO}_{4}\left(\mathrm{H}_{2} \mathrm{O}\right)\left(M^{\mathrm{II}}=\mathrm{Co}, \mathrm{Cu}, \mathrm{Zn}, \mathrm{Mg}\right)$ series for which unit-cell parameters are listed in Table 5.

$\mathrm{MnHAsO}_{4}\left(\mathrm{H}_{2} \mathrm{O}\right)$ has the same point symmetry and very similar unit-cell parameters and atomic coordinates for $\mathrm{Mn}$, As and $\mathrm{O}$ as the analogous $\mathrm{Co}, \mathrm{Zn}, \mathrm{Mg}$ compounds, and to a certain extent also for the $\mathrm{Cu}$ analogue. Since the crystal structures of the latter phases have been described in detail, here only the principal building units are

Table 5: Unit-cell parameters of triclinic $M^{\prime \prime} \mathrm{HAsO}_{4}\left(\mathrm{H}_{2} \mathrm{O}\right)$ compounds $(Z=8$, space group $P \overline{1})$ at room temperature.

\begin{tabular}{llrrrr}
\hline $\boldsymbol{M}$ & $\mathbf{M n}$ & $\mathbf{C o}$ & $\mathbf{C u}^{\mathrm{a}}$ & $\mathbf{Z n}$ & $\mathbf{M g}$ \\
\hline$a / \AA$ & $8.0105(16)$ & $7.865(3)$ & $8.093(2)$ & $7.948(2)$ & $7.8702(7)$ \\
$b / \AA$ & $15.991(4)$ & $15.699(6)$ & $15.764(3)$ & $15.829(5)$ & $15.8081(6)$ \\
$c / \AA$ & $6.8029(12)$ & $6.719(2)$ & $6.433(1)$ & $6.668(2)$ & $6.6389(14)$ \\
$\alpha /{ }^{\circ}$ & $92.635(8)$ & $94.25(3)$ & $84.35(3)$ & $90.86(2)$ & $90.814(6)$ \\
$\beta /{ }^{\circ}$ & $96.589(9)$ & $96.89(3)$ & $95.53(3)$ & $96.56(2)$ & $96.193(6)$ \\
$\gamma /{ }^{\circ}$ & $90.151(8)$ & $90.28(3)$ & $93.35(3)$ & $90.05(2)$ & $90.094(7)$ \\
$V / \AA^{3}$ & $864.7(3)$ & 821.28 & 811.93 & 833.3 & 821.06 \\
Ref. & This work & {$[34]$} & {$[42]$} & {$[40]$} & {$[43]$} \\
\hline
\end{tabular}

${ }^{\mathrm{a}}$ Original cell transformed with the matrix $(001,100,010)$. discussed. Common to all $M^{\mathrm{II}} \mathrm{HAsO}_{4}\left(\mathrm{H}_{2} \mathrm{O}\right)$ crystal structures is the formation of sheets stacked along the longest unitcell axis which is the $b$ axis according to the typically used unit-cell setting (Table 5). Like in the monoclinic krautite crystal structure, the two-dimensional framework is constructed from edge-sharing cis- $\left[\mathrm{M}\left(\mathrm{H}_{2} \mathrm{O}\right) \mathrm{O}_{5}\right](\mathrm{Mn} 2, \mathrm{Mn} 4$ for $\mathrm{MnHAsO}_{4}\left(\mathrm{H}_{2} \mathrm{O}\right)$ ) and $\left[M\left(\mathrm{H}_{2} \mathrm{O}\right)(\mathrm{OH}) \mathrm{O}_{4}\right]$ ( $\mathrm{Mn1}$ and $\left.\mathrm{Mn} 3\right)$ octahedra linked into zig-zag chains extending parallel [101] and intermediate $\mathrm{AsO}_{3}(\mathrm{OH})$ tetrahedra that link the chains into (010) sheets (Figure 4). Again, adjacent sheets are solely linked through hydrogen-bonding interactions. The commonly observed contact twinning on (010) in the triclinic $M^{\mathrm{II}} \mathrm{HAsO}_{4}\left(\mathrm{H}_{2} \mathrm{O}\right)$ structures (note that the $\mathrm{Cu}$ dominant mineral geminite has its name from Latin gemini meaning twins) can also be attributed to the layered arrangement of the crystal structure.

Notwithstanding that in none of the published $M^{\mathrm{II}} \mathrm{HAsO}_{4}\left(\mathrm{H}_{2} \mathrm{O}\right)$ structures $\mathrm{H}$ atom positions could be determined, the analysis of As-O bond lengths and BVS parameters (Tables 3 and 4) made it possible to identify all $\mathrm{O}$ atoms that are part of a water molecule or an $\mathrm{OH}$ group. In all crystal structures of the triclinic $M^{\mathrm{II}} \mathrm{HAsO}_{4}\left(\mathrm{H}_{2} \mathrm{O}\right)$ series, the $\mathrm{O}$ atoms of the four water molecules (for the $\mathrm{Mn}$ member 03, 07, 09, 011) are the same, whereas the $\mathrm{O}$ atoms belonging to $\mathrm{OH}$ groups are different for the $M^{\mathrm{II}}=\mathrm{Mn}$, Co, $\mathrm{Cu}$ set (for the Mn member O13, O15, 017, O18) compared to the $M^{\mathrm{II}}=\mathrm{Zn}, \mathrm{Mg}$ set $(06,012,014,020)$. As previously noted, all related non- $\mathrm{H}$ atoms in the five $M^{\mathrm{II}} \mathrm{HAsO}_{4}\left(\mathrm{H}_{2} \mathrm{O}\right)$ structures have the same point symmetry and similar coordinates, and all phases crystallize in the same space group type with similar unit-cells. However, the different hydrogen bonding schemes in the $M^{\mathrm{II}}=\mathrm{Mn}, \mathrm{Co}$, Cu set and the $M^{\mathrm{II}}=\mathrm{Zn}, \mathrm{Mg}$ set have a clear impact on the structural

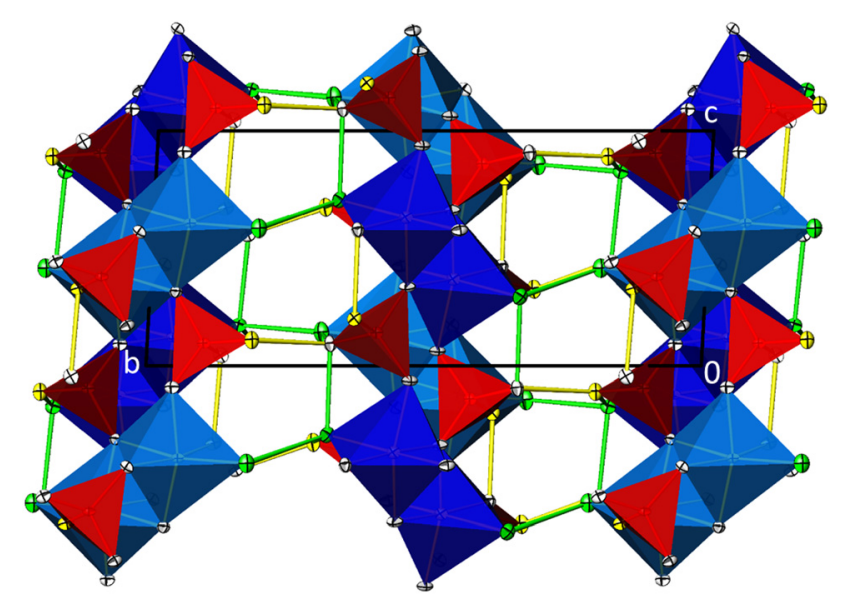

Figure 4: Crystal structure of triclinic $\mathrm{MnHAsO}_{4}\left(\mathrm{H}_{2} \mathrm{O}\right)\left(-173^{\circ} \mathrm{C}\right.$ data $)$ in polyhedral representation viewed along [100]. Displacement ellipsoids and color codes are as in Figure 3. 
Table 6: Absolute atomic displacements (in $\AA$ ) of triclinic $M^{\prime \prime} \mathrm{HAsO}_{4}\left(\mathrm{H}_{2} \mathrm{O}\right)$ compounds relative to $\mathrm{MnHAsO}_{4}\left(\mathrm{H}_{2} \mathrm{O}\right.$ ), as well as lattice distortion $(S)$, maximum distance $d_{\max }$ (in $\AA$ ), arithmetic mean distance $d_{\text {av }}$ (in $\AA$ ) and measure of similarity $(\Delta)$. For all structures, the original atom labelling was used; $\mathrm{O}$ atoms that are part of an $\mathrm{OH}$ group are underlined, $\mathrm{O}$ atoms that are part of a water molecule are marked with asterisks.

\begin{tabular}{|c|c|c|c|c|c|c|c|c|}
\hline \multirow{2}{*}{$\frac{M n}{M n 1}$} & \multicolumn{2}{|c|}{ Co } & \multicolumn{2}{|c|}{$\mathrm{Cu}$} & \multicolumn{2}{|c|}{$\mathrm{Zn}$} & \multicolumn{2}{|c|}{ Mg } \\
\hline & Co1 & 0.0642 & Cu4 & 0.2549 & Zn1 & 0.1311 & Mg1 & 0.1320 \\
\hline Mn2 & $\mathrm{Co} 2$ & 0.0387 & Cu2 & 0.1279 & $\mathrm{Zn} 2$ & 0.1242 & Mg2 & 0.0828 \\
\hline Mn3 & $\mathrm{Co3}$ & 0.0920 & Cu3 & 0.1305 & Zn3 & 0.0665 & Mg3 & 0.0810 \\
\hline Mn4 & Co4 & 0.0399 & Cu1 & 0.1374 & Zn4 & 0.1505 & Mg4 & 0.1038 \\
\hline As1 & As1 & 0.0295 & As4 & 0.3889 & As1 & 0.2590 & As1 & 0.2093 \\
\hline As2 & As2 & 0.0489 & As3 & 0.2215 & As2 & 0.2343 & As2 & 0.2221 \\
\hline As3 & As3 & 0.0663 & As1 & 0.2154 & As3 & 0.2380 & As3 & 0.1838 \\
\hline As4 & As4 & 0.0655 & As2 & 0.1703 & As4 & 0.2476 & As4 & 0.2281 \\
\hline 01 & 01 & 0.0182 & 012 & 0.2112 & 01 & 0.0694 & 01 & 0.0885 \\
\hline 02 & 02 & 0.0311 & 011 & 0.2716 & 02 & 0.1261 & 02 & 0.1170 \\
\hline $03 W^{*}$ & $03 *$ & 0.1550 & $\mathrm{H} 2 \mathrm{O}(4)^{\star}$ & 0.3795 & $03 *$ & 0.2605 & OW3* & 0.2898 \\
\hline 04 & 04 & 0.0159 & 02 & 0.1746 & 04 & 0.1171 & 04 & 0.1026 \\
\hline 05 & 05 & 0.0703 & 08 & 0.1262 & 05 & 0.2448 & 05 & 0.2172 \\
\hline 06 & 06 & 0.1123 & 01 & 0.4135 & $\underline{06}$ & 0.1788 & $\underline{\mathrm{OH} 6}$ & 0.0724 \\
\hline $07 W^{*}$ & $07^{*}$ & 0.0693 & $\mathrm{H} 2 \mathrm{O}(2)^{\star}$ & 0.5154 & $\overline{07^{*}}$ & 0.4666 & $\overline{\mathrm{OW}} 7^{\star}$ & 0.4573 \\
\hline 08 & 08 & 0.0796 & 07 & 0.2188 & 08 & 0.0802 & 08 & 0.0821 \\
\hline 09W* & 09* & 0.1232 & $\mathrm{H} 2 \mathrm{O}(3)^{\star}$ & 0.5792 & 09* & 0.4531 & OW9* & 0.4643 \\
\hline 010 & 010 & 0.0702 & 05 & 0.1728 & 010 & 0.0525 & 010 & 0.0668 \\
\hline $011 W^{*}$ & 011 & 0.1491 & $\mathrm{H} 2 \mathrm{O}(1)^{\star}$ & 0.3620 & $011^{*}$ & 0.3425 & OW11* & 0.3097 \\
\hline 012 & 012 & 0.0224 & 010 & 0.4768 & $\underline{012}$ & 0.2027 & $\underline{\mathrm{OH} 12}$ & 0.1356 \\
\hline$\underline{013 \mathrm{H}}$ & 013 & 0.1233 & $\underline{\mathrm{OH} 4}$ & 0.8540 & $\overline{013}$ & 0.3303 & $\overline{013}$ & 0.3040 \\
\hline 014 & $\overline{014}$ & 0.0605 & 09 & 0.3558 & $\underline{014}$ & 0.1708 & $\underline{\mathrm{OH} 14}$ & 0.1336 \\
\hline$\underline{015 \mathrm{H}}$ & $\underline{015}$ & 0.0552 & $\underline{\mathrm{OH} 3}$ & 0.3791 & $\overline{015}$ & 0.1493 & $\overline{015}$ & 0.1599 \\
\hline$\overline{016}$ & $\overline{016}$ & 0.0846 & $\overline{03}$ & 0.0536 & 016 & 0.0726 & 016 & 0.0777 \\
\hline$\underline{017 \mathrm{H}}$ & $\underline{017}$ & 0.1231 & $\underline{\mathrm{OH} 1}$ & 0.5148 & 017 & 0.2275 & 017 & 0.1445 \\
\hline$\overline{\mathrm{O} 18 \mathrm{H}}$ & $\overline{018}$ & 0.0428 & $\overline{\mathrm{OH} 2}$ & 0.3456 & 018 & 0.1801 & 018 & 0.1785 \\
\hline$\overline{019}$ & $\overline{019}$ & 0.0413 & $\overline{06}$ & 0.1189 & 019 & 0.2480 & 019 & 0.2172 \\
\hline 020 & 020 & 0.0690 & 04 & 0.3302 & $\underline{020}$ & 0.2901 & $\underline{\mathrm{OH} 20}$ & 0.2522 \\
\hline $\mathrm{S}$ & 0.0125 & & 0.0455 & & $\overline{0.0110}$ & & $\overline{0.0134}$ & \\
\hline$d_{\max }$ & 0.1550 & & 0.8540 & & 0.4666 & & 0.4643 & \\
\hline$d_{\mathrm{av}}$ & 0.0701 & & 0.3036 & & 0.2041 & & 0.1826 & \\
\hline$\Delta$ & 0.018 & & 0.158 & & 0.052 & & 0.034 & \\
\hline
\end{tabular}

relationships among the $M^{\mathrm{II}} \mathrm{HAsO}_{4}\left(\mathrm{H}_{2} \mathrm{O}\right)$ compounds. The crystal structures among the members of each set are isotypic, whereas the crystal structures between the two sets are isopointal [50].

The differences caused by replacement of the cation within the triclinic $M^{\mathrm{II}} \mathrm{HAsO}_{4}\left(\mathrm{H}_{2} \mathrm{O}\right)(M=\mathrm{Co}, \mathrm{Cu}, \mathrm{Zn}, \mathrm{Mg})$ crystal structures were quantified with the program compstru [51], available at the Bilbao Crystallographic Server [52]. Atomic displacements for all atom pairs in the five structures as well as numerical values for the degree of lattice distortion $(S)$, the maximum distance $\left(d_{\max }\right)$ between the atomic positions of paired atoms, the arithmetic mean of all distances $\left(d_{\mathrm{av}}\right)$ and the measure of similarity $(\Delta)$ are compiled in Table 6 , with triclinic $\mathrm{MnHAsO}_{4}\left(\mathrm{H}_{2} \mathrm{O}\right)$ as the reference structure. The low values for $\Delta, d_{\mathrm{av}}$ and $d_{\text {max }}$ between isotypic $\mathrm{MnHAsO}_{4}\left(\mathrm{H}_{2} \mathrm{O}\right)$ and
$\mathrm{CoHAsO}_{4}\left(\mathrm{H}_{2} \mathrm{O}\right)$ reveal a high similarity of the two structures. In comparison, all these values between triclinic $\mathrm{MnHAsO}_{4}\left(\mathrm{H}_{2} \mathrm{O}\right)$ and the two isopointal crystal structures of $\mathrm{ZnHAsO}_{4}\left(\mathrm{H}_{2} \mathrm{O}\right)$ and $\mathrm{MgHAsO}_{4}\left(\mathrm{H}_{2} \mathrm{O}\right)$ are much higher. In these cases, the highest displacements of related atom pairs are developed between the $\mathrm{O}$ atoms of water or $\mathrm{OH}$ groups participating as donor atoms in the hydrogenbonding network. Although $\mathrm{MnHAsO}_{4}\left(\mathrm{H}_{2} \mathrm{O}\right)$ and CuHAs$\mathrm{O}_{4}\left(\mathrm{H}_{2} \mathrm{O}\right)$ are considered as being isotypic due to the same type of hydrogen-bonding network, the values for $S, \Delta, d_{\mathrm{av}}$ and $d_{\max }$ are by far the highest in the $M^{\mathrm{II}} \mathrm{HAsO}_{4}\left(\mathrm{H}_{2} \mathrm{O}\right)$ series. The comparatively high strain in the crystal structure of $\mathrm{CuHAsO}_{4}\left(\mathrm{H}_{2} \mathrm{O}\right)$ relative to $\mathrm{MnHAsO}_{4}\left(\mathrm{H}_{2} \mathrm{O}\right)$ can be attributed to the Jahn-Teller distortions of the $\left[\mathrm{CuO}_{6}\right]$ octahedra. The distortion with its usual splitting into four short equatorial and two long axial $\mathrm{Cu}-\mathrm{O}$ distances affects also the 
positions of the $\mathrm{O}$ atoms of water molecules or $\mathrm{OH}$ groups that are bonded to the $\mathrm{Cu}^{\mathrm{II}}$ cations (some are part of the shorter, some of the longer $\mathrm{Cu}-\mathrm{O}$ bonds), and consequently also their roles in the hydrogen-bonding scheme. All in all, the crystal structure of the $\mathrm{Cu}$ member exhibits a low similarity to the Mn member and to all other members of the $M^{\mathrm{II}} \mathrm{HAsO}_{4}\left(\mathrm{H}_{2} \mathrm{O}\right)$ series.

\section{Conclusions}

The present study revealed dimorphism for the phase $\mathrm{MnHAsO}_{4}\left(\mathrm{H}_{2} \mathrm{O}\right)$. The crystal structure of natural, chemically pure monoclinic krautite was re-evaluated on the basis of single-crystal X-ray diffraction data from a cotype specimen. The results confirm the previously published structure model in space group $P 2_{1}$, but with considerably higher precision and accuracy. In contrast to other previous studies that reported monoclinic symmetry for synthetic $\mathrm{MnHAsO}_{4}\left(\mathrm{H}_{2} \mathrm{O}\right)$ crystals, we found that the symmetry of crystals prepared under mild hydrothermal conditions $\left(105^{\circ} \mathrm{C}\right.$, autogenous pressure) is triclinic. Since, as noted above, crystals prepared in the same way at $90{ }^{\circ} \mathrm{C}$ and apparently at any temperature between room temperature and $90^{\circ} \mathrm{C}$, crystallize in space group $P 2_{1}$, the temperature of formation influences the crystal symmetry, probably due to a preference for a different hydrogen-bonding scheme at higher temperature. This contradicts the general experience that high-temperature polymorphs usually have higher symmetries than their low-temperature analogues. The crystal structure of the triclinic $\mathrm{MnHAsO}_{4}\left(\mathrm{H}_{2} \mathrm{O}\right)$ polymorph is isotypic with $\mathrm{CoHAsO}_{4}\left(\mathrm{H}_{2} \mathrm{O}\right)$ and $\mathrm{CuHAsO}_{4}\left(\mathrm{H}_{2} \mathrm{O}\right)$ and isopointal with $\mathrm{ZnHAsO}_{4}\left(\mathrm{H}_{2} \mathrm{O}\right)$ and $\mathrm{MgHAsO}_{4}\left(\mathrm{H}_{2} \mathrm{O}\right)$. Although similarities between the monoclinic and triclinic forms of $\mathrm{MnHAsO}_{4}\left(\mathrm{H}_{2} \mathrm{O}\right)$ are apparent, there exists no direct group-subgroup relation between the two crystal structures. According to the available single-crystal X-ray diffraction data of the two modifications, possible temperature-dependent phase transitions do not occur between room temperature and $-173^{\circ} \mathrm{C}$. Future studies with respect to formation conditions as well as thermal analyses of the monoclinic and triclinic polymorphs are required to obtain a deeper understanding of their stability fields and thermodynamic properties.

Acknowledgment: The authors acknowledge TU Wien Bibliothek for financial support through its Open Access Funding Program and the X-ray centre of TU Wien for providing access to the single-crystal and powder diffractometers.
Author contributions: All the authors have accepted responsibility for the entire content of this submitted manuscript and approved submission.

Research funding: None declared.

Conflict of interest statement: The authors declare no conflicts of interest regarding this article.

\section{References}

1. Dearborn F. E. J. Econ. Entomol. 1930, 23, 630-635.

2. Bencko V., Yan Li Foong F. Ann. Agric. Environ. Med. 2017, 24, 312-316.

3. Smedley P. L., Kinniburgh D. G. Appl. Geochem. 2002, 17, 517-568.

4. Smith A. H., Lingas E. O., Rahman M. Bull. World Health Organ. 2000, 78, 1093-1103.

5. Schroffenegger M., Eder F., Weil M., Stöger B., Schwendtner K., Kolitsch U. J. Alloys Compd. 2020, 820, 153369.

6. Belsky A., Hellenbrandt M., Karen V. L., Luksch P. Acta Crystallogr. 2002, 58, 364-369.

7. Weil M., Kremer R. K. J. Solid State Chem. 2017, 245, 115-126.

8. Weil M., Stöger B. Acta Crystallogr B. 2010, 66, 603-614.

9. Nakua A. M., Greedan J. E. J. Solid State Chem. 1995, 118, 402-411.

10. Aranda M. A. G., Attfield J. P., Bruque S. Inorg. Chem. 1993, 32, 1925-1930.

11. Priestner M., Singer G., Weil M., Kremer R. K., Libowitzky E. J. Solid State Chem. 2019, 277, 209-215.

12. Aranda M. A. G., Bruque S., Attfield J. P. Inorg. Chem. 1991, 30, 2043-2047.

13. Stock N., Stucky G. D., Cheetham A. K. Z. Naturforsch 2001, 56b, 359-363.

14. Weil M. Inorganics 2019, 7, 1-12.

15. Moore P. B., Araki T. Am. Mineral. 1979, 64, 390-401.

16. Kampf A. R., Cámara F., Ciriotti M. E., Nash B. P., Balestra C., Chiappino L. Eur. J. Mineral 2016, 28, 687-696.

17. Stock N., Stucky G. D., Cheetham A. K. Z. Anorg. Allg. Chem. 2002, 628, 357-362.

18. Yang Y. W., Stevenson R. A., Siegel A. M., Downs G. W. Acta Crystallogr. 2011, E67, i68.

19. Moore P. B., Molin-Case J. Am. Mineral. 1971, 56, 1539-1551.

20. Moore P. B., Sen Gupta P. K., Schlemper E. O. Am. Mineral. 1989, 74, 256-262.

21. Moore P. B. Am. Mineral. 1968, 53, 733-741.

22. Rojo J. M., Larranaga A., Mesa J. L., Urtiaga M. K., Pizarro J. L., Arriortua M. I., Rojo T. J. Solid State Chem. 2002, 165, 171-177.

23. Kolitsch U. Acta Crystallogr . 2001, E57, 115-118.

24. Moore P. B. Am. Mineral. 1970, 55, 2023-2037.

25. Catti M., Franchini-Angela F. Am. Mineral. 1979, 64, 1248-1254.

26. Kampf A. R. Am. Mineral. 2009, 94, 1535-1540.

27. Callegari A. M., Boiocchi M., Ciriotti M. E., Balestra C. Am. Mineral. 2012, 97, 727-734.

28. Graeser S., Schwander H., Bianchi R., Pilati T., Gramaccioli C. M. Am. Mineral. 1989, 74, 676-684.

29. Deiß E. Kolloid Z. 1914, 14, 139-146.

30. Apex-3, Saint, Cell_now, Twinabs. Bruker AXS Inc: Madison, WI (USA), 2012. 
31. Krause L., Herbst-Irmer R., Sheldrick G. M., Stalke D. J. Appl. Crystallogr. 2015, 48, 3-10.

32. Sheldrick G. M. Acta Crystallogr. 2015, A71, 3-8.

33. Sheldrick G. M. Acta Crystallogr. 2015, C71, 3-8.

34. Zettler F., Riffel H., Hess H., Keller P. Z. Anorg. Allg. Chem. 1979, 454, 134-144.

35. Flack H. D. Acta Crystallogr. 1983, A39, 876-881.

36. Brown I. D. The Chemical Bond in Inorganic Chemistry: The Bond Valence Model; Oxford University Press: Oxford, UK, 2002.

37. Brese N. E., O’Keeffe M. Acta Crystallogr. 1991, B47, 192-197.

38. Fontan F., Orliac M., Permingeat F. Bull. Soc. Fr. Mineral. Cristallogr. 1975, 98, 578-584.

39. Schmetzer K., Horn W., Medenbach O. Neues Jahrb. Mineral., Monatsh. 1981, 257-266.

40. Keller P., Hess H., Riffel H. Neues Jahrb. Mineral., Abh. 1980, 138, 316-332.

41. Cooper M. A., Hawthorne F. C. Can. Mineral. 1995, 33, 1111-1118.

42. Prensipe M., Pushcharovskii D. Yu., Sarp H., Ferraris G. Vestn. Mosk. Univ., Ser. 4: Geol. 1996, 66-74.
43. Kampf A. R., Nash B. P., Dini M., Molina Donoso A. A. Mineral. Mag. 2013, 77, 3081-3092.

44. Yuan T. C., Jia Y. F., Demopoulos G. P. Can. Metall. Q. 2005, 44, 449-456.

45. Bramwell S. T., Buckley A. M., Rosseinsky M. J., Day P. New J. Chem. 1994, 18, 1209-1214.

46. Beneke K., Lagaly G. Am. Mineral. 1981, 66, 432-435.

47. Gagné O. C., Hawthorne F. C. IUCrJ 2020, 7, 581-629.

48. Schwendtner K., Kolitsch U. Acta Crystallogr. 2019, C75, 1134-1141.

49. Müller U. Symmetry Relationships Between Crystal Structures; Oxford University Press: Oxford, 2013.

50. Lima-De-Faria J., Hellner E., Liebau F., Mackovicky E., Parthé E. Acta Crystallogr. 1990, A46, 1-11.

51. de la Flor G., Orobengoa D., Tasci E., Perez-Mato J. M., Aroyo M. I. J. Appl. Crystallogr. 2016, 49, 653-664.

52. Aroyo M. I., Perez-Mato J. M., Capillas C., Kroumova E., Ivantchev S., Madariaga G., Kirov A., Wondratschek H. Z. Kristallogr 2006, 221, 15-27. 